\title{
Arctic tsunamis threaten coastal landscapes and communities - survey of Karrat Isfjord 2017 tsunami effects in Nuugaatsiaq, western Greenland
}

\author{
Mateusz C. Strzelecki ${ }^{1,2}$ and Marek W. Jaskólski ${ }^{1,3,4}$ \\ ${ }^{1}$ Institute of Geography and Regional Development, University of Wrocław, pl. Uniwersytecki 1, 50-137 Wrocław, Poland \\ ${ }^{2}$ Alfred Wegener Institute, Helmholtz Centre for Polar and Marine Research, Permafrost Research, 14473 Potsdam, Germany \\ ${ }^{3}$ Leibniz Institute of Ecological Urban and Regional Development, Environmental Risks in Urban \\ and Regional Development, Weberplatz 1, 01217 Dresden, Germany \\ ${ }^{4}$ Interdisciplinary Centre for Ecological and Revitalizing Urban Transformation, \\ Gottfried-Kiesow-Platz 1, 02826 Görlitz, Germany
}

Correspondence: Mateusz C. Strzelecki (mateusz.strzelecki@uwr.edu.pl) and

Marek W. Jaskólski (marek.jaskolski@uwr.edu.pl)

Received: 9 November 2019 - Discussion started: 2 January 2020

Revised: 8 August 2020 - Accepted: 27 August 2020 - Published: 24 September 2020

\begin{abstract}
On the 17 June 2017, a massive landslide which mobilized $35-58$ million $\mathrm{m}^{3}$ of material entered the Karrat Isfjord in western Greenland. It triggered a tsunami wave with a runup height exceeding $90 \mathrm{~m}$ close to the landslide, ca. $50 \mathrm{~m}$ on the opposite shore of the fjord. The tsunami travelled ca. $32 \mathrm{~km}$ along the fjord and reached the settlement of Nuugaatsiaq with ca. 1-1.5 m high waves which flooded the terrain up to $9 \mathrm{~m}$ a.s.l. (above sea level). Tsunami waves were powerful enough to destroy the community infrastructure, impact fragile coastal tundra landscape, and unfortunately injure several inhabitants and cause four deaths. Our field survey carried out 25 months after the event results in documentation of the previously unreported scale of damage in the settlement (ca. $48 \%$ of infrastructure objects including houses and administration buildings were destroyed by the tsunami). We have observed a recognizable difference in the concentration of tsunami deposit accumulations between areas of the settlement overwashed by the wave and areas of runup and return flow. The key tsunami effects preserved in the coastal landscape were eroded coastal bluffs, gullied and dissected edges of cliffed coast in the harbour, and tundra vegetation compressed by boulders or icebergs rafted onshore during the event.
\end{abstract}

\section{Introduction}

Although known to the research community for at least 60 years, the occurrence, scale, and impacts of tsunamis in cold regions (Arctic and subarctic) still shock the wider public. Their increasing frequency in this rapidly warming region already poses a serious threat to a fragile polar coastal environment and infrastructural needs of human communities (Miller, 1960; Dahl-Jensen et al., 2004; Buchwał et al., 2015; Higman, 2018).

The unstable nature of cold region landscapes in terms of landslides induced by permafrost thawing or glacier retreat - or earthquakes - provides potential tsunami sources. The effects of waves are particularly destructive in fjords and narrow straits, where a constraining topography can amplify the wave heights. For instance, the landslide which entered Lituya Bay in Alaska in 1958 triggered a giant tsunami wave with a runup height of over $500 \mathrm{~m}$ (Miller, 1960). Another wave (runup over $190 \mathrm{~m}$ ) recorded in 2015 in Taan Fjord, Alaska, was caused by a landslide from local slopes destabilized by the retreat of Tyndall Glacier (Dufresne et al., 2018; Higman et al., 2018; Haeussler et al., 2018; Bloom et al., 2020). In the last hundred years tsunamis were also recorded in Norwegian fjords, e.g. the Tafjord 1934 event (e.g. Harbitz et al., 2014). 
In Greenland, due to the recent climate change (i.e. shrinking of glaciers and permafrost thawing) many mountain slopes were destabilized and released numerous tsunamigenic landslides. For example, in November 2000 a landslide from Paatuut mountain triggered a tsunami (runup ca. $50 \mathrm{~m}$ ) which destroyed Qullissat town (Disko Island, western Greenland) and destabilized shores along Sullorsuaq Strait even up to $150 \mathrm{~km}$ from the landslide site (Dahl-Jensen et al., 2004; Buchwał et al., 2015). The same region was also hit by a tsunami after the Niiortuut landslide in 1952, as mentioned in the recent inventory of Greenland landslides carried out by Svennevig (2019).

Here we report on the largest documented tsunami wave in Greenland to date (runup height ca. $90 \mathrm{~m}$ ), which resulted from a massive landslide to Karrat Isfjord and destroyed the settlement of Nuugaatsiaq on 17 June 2017 (Fig. 1). Based on a field survey carried out 2 years after the event, our study provides insights into the lasting tsunami-induced geo-ecological changes in coastal landscape and in addition presents an inventory of tsunami damages to settlement infrastructure.

\section{Materials and methods}

This study is based on field observations carried out in July 2019. We followed the post-tsunami trace mapping protocol described in the seminal paper of Szczuciński (2012) on post-depositional changes of onshore tsunami deposits. It is important to note that the visit occurred 25 months after the event, which means that at least two spring meltout seasons happened between the event and the mapping. It is likely that some of the tsunami traces (particularly fine deposits, tsunami salt precipitation, and iceberg erosional and depositional marks) were partly erased from the landscape. The largest boulders and litter lines were marked with a handheld GPS. We took a careful survey of the vegetation cover change, as suggested by Buchwał et al. (2015) in their study of 2000 Paatuut tsunami impact on an Arctic shrub ecosystem. We photographed each settlement building or facility (e.g. cemetery, playground, harbour, heliport) and noted any visible infrastructure and landscape degradation. We observed some signs of human action on the site, focused on removing most of the toxic substances left in the settlement, that is petrol. In order to properly understand the scale of post-tsunami changes, we compared a series of aerial images (available at NunaGIS portal: https://nunagis-asiaq. hub.arcgis.com/, last access: 11 October 2019), field photos, online video taken in the settlement before and after the wave, and settlement spatial planning maps and risk assessment documents published by the local government. Apart from land-based photos, we collected a number of aerial images using a DJI Mavic Pro drone. As our unmanned aerial vehicle (UAV) was not allowed to enter the no-fly zone above the settlement centre, we took oblique images from

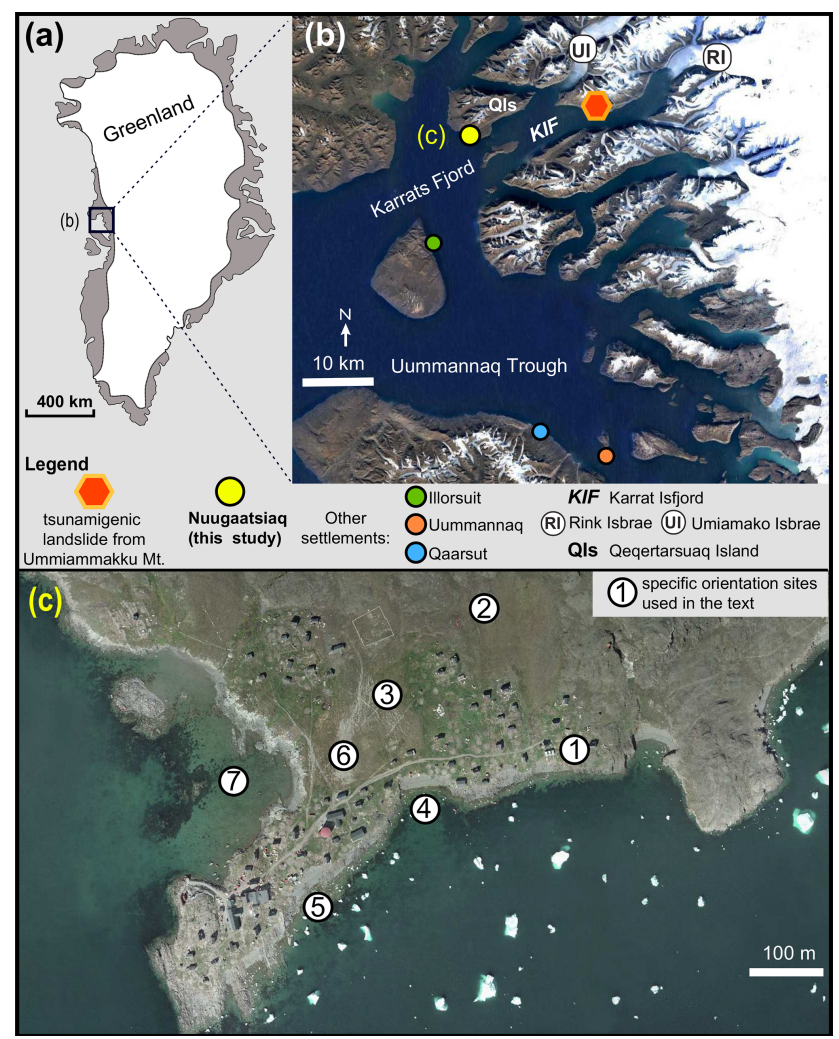

Figure 1. Location of study area. (a) General position of Karrat Fjord in western Greenland (source: (C) Google Earth); (b) Karrat Fjord area, where tsunamigenic landslide occurred on 17 June 2017 and inundated the settlement of Nuugaatsiaq; (c) aerial image of Nuugaatsiaq before the event (nunuagis.gl). Numbers in circles mark orientation sites used in the text: 1 - area with first line of buildings destructed by tsunami; 2 - heliport above the tsunami inundation limit; 3 - playground area, partly flooded by tsunami; 4 first beach eroded by tsunami; 5 - second beach eroded by tsunami; 6 - saddle between beach (4) and harbour; 7 - local harbour.

the recommended distance. We have also explored ArcticDEM (Porter et al., 2018) resources and compared terrain changes between pre- and post- tsunami digital terrain models (DTMs) to determine the scale of coastal landscape modification entailed by tsunami impact. In ESRI ArcGIS software a $2 \mathrm{~m}$ DTM constructed from satellite images captured on 11 September 2016 was subtracted from DTM captured on 19 June 2017 to calculate elevation difference between models and check if sites where tsunami erosion and deposition detected during fieldwork were traceable in digital terrain models (Fig. 6). Information about landslide genesis and some of the tsunami wave characteristics was extracted from remote-sensing analyses produced by USGS (BessetteKirton et al., 2017) and the collection of geophysical reports published soon after the event (Clinton et al., 2017; Chao et al., 2018; Gauthier et al., 2018; Butler, 2019; Poli, 2017; Paris et al., 2019). 


\section{Research area}

\subsection{Geographical setting}

The surrounding landscape is mountainous (mountain ranges with numerous summits and plateaus reaching $2000 \mathrm{~m}$ a.s.l.) and is characterized by some of the highest relief in western Greenland (Roberts et al., 2013). The major role in shaping the present-day geomorphology was played by retreat of Uummannaq ice stream system (UISS) which left the diverse set of glacial land systems in fjords, mountains, and valleys of the region. The landscape was dissected by selective linear glacial erosion with lowlands dominated by glacial scour and mountain ranges occupied by cirque, plateaus, and valley-type glaciers (Lane et al., 2016). Lane et al. (2016) classified banks of Karrat fjord and southern coasts of Qeqertarsuaq island, where the studied settlement is located, to areal scour terrestrial land system exposed after the retreat of two northern branches of UISS (Umiamako Isbrae and Rink Isbrae). Ice streams significantly modelled the topography of local fjords. Dowdeswell et al. (2016) described the submarine landscape (Rink Fjord and Karrat Isfjord) as a system with relatively smooth sea floor, broken by bedrock ridges and pinnacles that divide the fjord into several deep basins. Bathymetry maps derived from multibeam echo-sounding data acquired in 2007-2014 and compiled by Rignot et al. (2016) revealed that the entrance to Karrat Isfjord is $600 \mathrm{~m}$ deep, $5 \mathrm{~km}$ wide, and with a sill at $400 \mathrm{~m}$ depth about $160 \mathrm{~km}$ from Rink Isbrae The deepest basin of the fjord $(1100 \mathrm{~m})$ is located ca. $25 \mathrm{~km}$ to the east of Nuugaatsiaq. The fjord near the settlement is shallow with sea floor depths of $0-240 \mathrm{~m}$.

The coastal landscape of Nuugaatsiaq is predominantly rocky with an undulating and ragged coastline dissected by narrow coves and headlands (Figs. 2a, 3). Rocky coves along the southern coast of Nuugaatsiaq are filled with narrow beaches underlaid by rocky bedrock (Fig. 2a). Beach deposits are thin $(<1 \mathrm{~m})$ and composed of mixed coarse sand and gravel deposits as well as boulders deposited by icebergs or left along the shores by retreating ice streams. The largest cape in the area, located to the SW of the settlement centre, is characterized by bare rocky surface with wellpreserved signs of glacial scour, e.g. striations and polished bedrock (Fig. 2b). Close to the shoreline most of smooth rocky hollows were filled with accumulations of boulders (ca. $0.2-0.5 \mathrm{~m}$ in diameter). The Nuugaatsiaq harbour (site 7 in Fig. 1c) is backed by the cliffed coast (between 2 and $4 \mathrm{~m}$ high) formed in bedrock and overlain by a layer of soils/glacial deposits and covered with well-vegetated tundra (Fig. 2c). At the base of the cliff narrow (1-3 m wide) mixed sand-gravelly beaches are present.

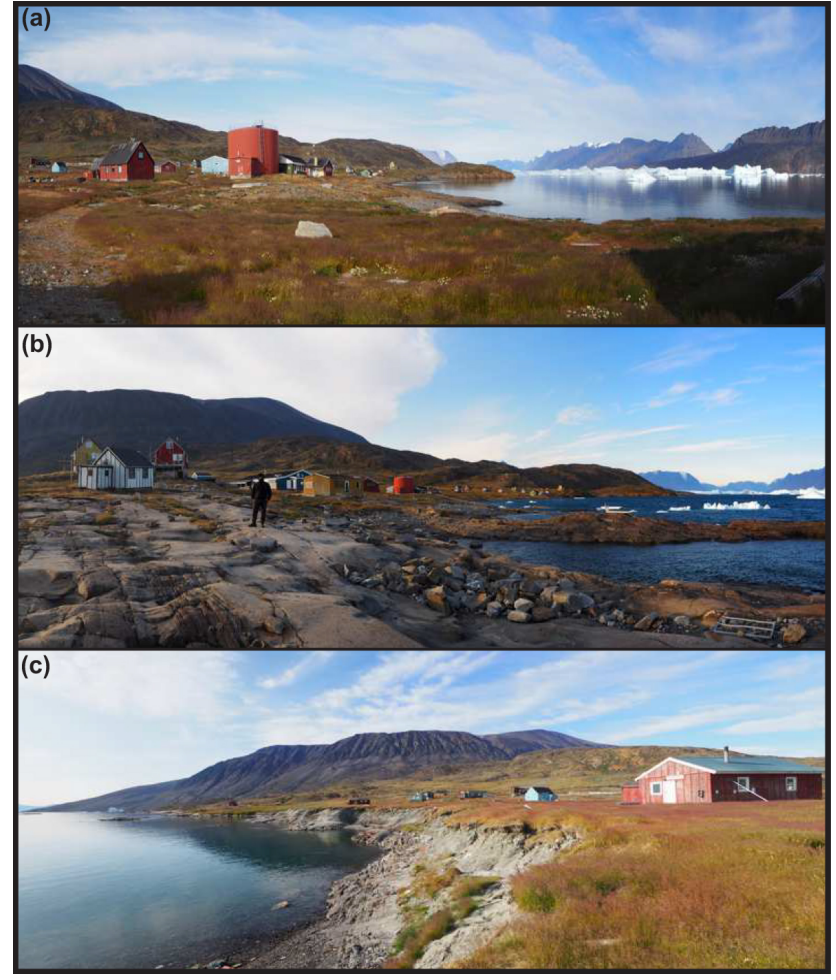

Figure 2. Coastal landscapes in Nuugaatsiaq. (a) Densely vegetated (grasses and shrubs) coastal lowland with ragged shoreline dissected by rocky capes and coves with narrow beaches. (b) Main headland with exposed glacially scoured bare rock surfaces; note accumulations of boulders in rocky hollows. (c) Cliffed coast in Nuugaatsiaq harbour. Tops of the cliff were eroded and gullied by tsunami.

\subsection{Geology}

The dominant rocks in the region are Archean gneisses mixed with supracrustal rocks of the Palaeoproterozoic Karrat Group (Sørensen and Guarnieri, 2018). The slopes of Ummiammakku mountain where the tsunamigenic landslide occurred are composed of gneisses (Archean) overlain by quartzites (Palaeoproterozoic) and schist of the so-called Karrat Group (Mott et al., 2013).

\subsection{Permafrost}

The study area was historically included in the continuous permafrost zone (Christiansen and Humlum, 2000). The most recent Northern Hemisphere permafrost map based on the modelling of temperature at the top of the permafrost (2000-2016) at the $1 \mathrm{~km}^{2}$ scale presented by Obu et al. (2019) places it close to the boundary zone between the continuous and discontinuous permafrost zones. To our knowledge no direct ground temperature measurements have been conducted in the close surroundings. 


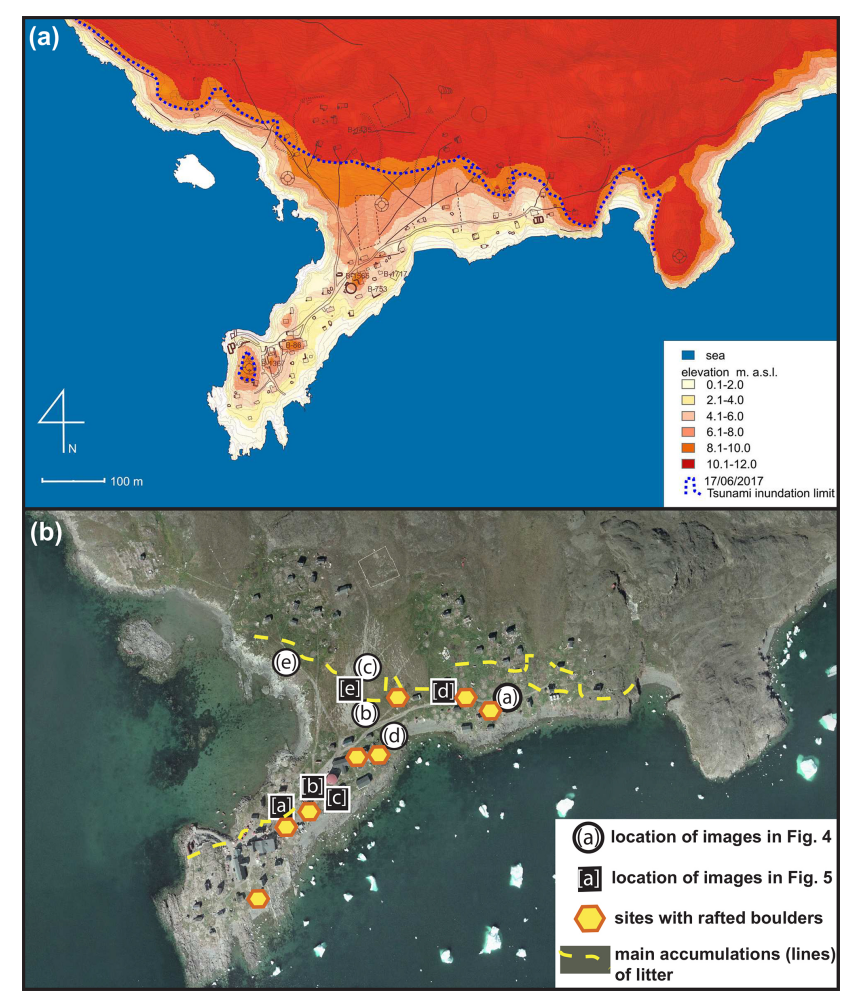

Figure 3. (a) Digital elevation model (2 m DEM, https://www.pgc. umn.edu/data/arcticdem/, last access: 21 March 2020) of Nuugaatsiaq with marked tsunami inundation limit (wave flooded the terrain up to 9 ma.s.1.). (b) Overview map of the settlement with marked location of images from Figs. 4 and 5. Lines of litter visible in the landscape 2 years after the event and sites where large boulders rafted by tsunami were marked too. Background: technical map of settlement from nunagis.gl.

\subsection{Vegetation}

This area is a part of the mid-arctic oceanic vegetation zone (Bay, 1997). The vegetation comprises a shrub-grassland system, with commonly found circumpolar species including Carex ursina, Cassiope heath, Salix glauca, Festuca groenlandica, and Puccinellia groenlandica. Coastal grasslands are dominated by dense Honckenyo-Elymetum mollis associations (Lepping and Daniëls, 2007).

\subsection{Settlement history \& economy}

Nuugaatsiaq is a settlement in the district of Uummannaq in the Avannaata Kommunia. Nuugaatsiaq is located in the south of the Qeqertarsuaq Island (Fig. 1), dominated by the Snehætten (Nuugaatsiap Qaqqaa) mountain range The island is separated from Karrat Island located between Karrat Fjord and Karrat Isfjord by the Torsuuk strait. The closest settlement is Illorsuit and lies about $35 \mathrm{~km}$ south-west.

Nuugaatsiaq was probably settled shortly after 1918. In 1923 it was proposed in Grønlands Landsråd to divide the municipality of Illorsuit. For this purpose, a new udsted (roughly translatable as outlying settlement) had to be built. Udsted were smaller trading settlements, which were administered by an udsted administrator. Most of the udsted later became villages. In 1925 Nuugaatsiaq was granted udsted status, and in the same year a dwelling was built for the udsted administrator. In 1926 the village received a school chapel. In 1930 Nuugaatsiaq already had 119 inhabitants. In the same year a shop with a warehouse was built, and in 1936 a packing house was built (Madsen, 2009). In 1960 the population reached its maximum with 159 people. In 2017 the settlement had 102 inhabitants (http://bank.stat.gl/, last access: 9 May 2020).

Nuugaatsiaq lives mainly from halibut fishing, while some time ago there was still seal hunting and catfish fishing. A small trading branch of Royal Greenland with a maximum of 10 employees stored the fish. Other jobs were in administration at Pilersuisoq (chain of all-purpose general stores), in tourism, and at Atuarfik Saamu School, which taught 12 students in grades one to nine and also offered a library and youth leisure activities. There was also a day care centre, the post office, an infirmary, and a village hall. The majority of the buildings were located on undulating coastal lowland from 1 to $4 \mathrm{~m}$ a.s.l. (Fig. 3a)

There is a small quay on the headland that gives the village its name. Most of the boats were usually launched directly at the water's edge in the small harbour on the west side. In the north is the heliport Nuugaatsiaq. In winter, the traffic was by snowmobile and dog sled.

Nukissiorfiit (state utility company) supplied the village with electricity via the power station in the east and with fresh water from the reservoir supplied by local streams. Garbage was burned or dumped into the sea. TELE Greenland provided the telecommunications.

The events of 17 June 2017 resulted in the evacuation of the settlement and abandonment of the community continuing to the present. Currently former inhabitants of Nuugaatsiag were relocated to the Uummannaq and Qaarsut settlement over $100 \mathrm{~km}$ south of Nuugaatsiaq (Fig. 1).

\section{Results and discussion}

\subsection{Landslide and tsunami characteristics}

According to the analysis of seismic precursors of the event carried out by Butler (2019), the tsunami was a direct result of the landslide triggered by the following sequence of processes. An earthquake ruptured the fault surface and released the hanging wall ca. $1000 \mathrm{~m}$ above the sea, and a head scarp was created. Rockfall was transformed into a rock avalanche which entered the fjord, causing the wave. Gauthier et al. (2018) calculations suggest that the Karrat fjord landslide was much larger $\left(\sim 35-58 \times 10^{6} \mathrm{~m}^{3}\right)$ than the famous tsunamigenic rockslide into Lituya Bay, Alaska, in 
$1958\left(\sim 30 \times 10^{6} \mathrm{~m}^{3}\right)$. Interestingly, on the map of the Nuussuaq Basin showing landslide-prone areas published by Pedersen et al. (2002), the Karrat Fjord region is not marked as a potential risk area.

A field survey carried out by a group of researchers led by Professor Fritz from the Georgia Institute of Technology (Schiermeier, 2017; https://ce.gatech.edu/news/afterrecon-trip-researchers-say-greenland-tsunami-june, last access: 20 September 2020) found evidence that the wave runup height was ca. $90 \mathrm{~m}$ at the landslide site and up to $50 \mathrm{~m}$ on the opposite side of the Karrat Fjord. Numerical modelling of the landslide and wave performed by Paris et al. (2019) indicates that Nuugaatsiaq located ca. $32 \mathrm{~km}$ from the landslide was hit by three $1-1.5 \mathrm{~m}$ high waves, inundating the settlement over a period of ca. $3 \mathrm{~min}$. The wave inundated terrain up to 9 ma.s.l. (Fig. 3a).

\subsection{Landscape degradation}

\subsubsection{Soil and tundra cover}

Inspection of satellite images and photographs taken in $\mathrm{Nu}$ ugaatsiaq before the event suggest that grassy-tundra covers dominated the top of coastal bluffs and the strip of coastal lowlands between the predominantly rocky shore and main coastal road passing the settlement from west to east. During our fieldwork we noticed very dense and relatively high $(0.4-0.6 \mathrm{~m})$ grassy meadows covering coastal lowlands and recolonized abandoned playgrounds, roads, and backyards (Fig. 2a). The observed post-event vegetation cover in the study area was significantly denser and higher than in other settlements visited in the region in the same season. About 2 years after the event most of the blocks of eroded soil, rafts of tundra, boulders, or litter that were found were almost entirely hidden in a high grass cover (Fig. 4a). The wave tore blocks of tundra (shrubs, mosses, grass) off the coastal slope and deposited them on land (Fig. 4b, c). We noted a significant removal of tundra cover, soil erosion, and associated formation of rills or small gullies (0.2-0.6 m deep) concentrated on surfaces exposed after the washing away of buildings. Tundra and soil were also eroded along the cliffed coast of the harbour (Fig. 4d, e). At a few places along the main road and in the vicinity of the playground the vegetation cover (grasses) was covered by a thin layer of tsunami deposits $(3-7 \mathrm{~cm})$ composed mainly of marine gravels mixed with coarser sands. Salty patches with dead vegetation were observed mainly across the saddle between the southern coast and western harbour (site 6 in Fig. 1c). After analysing the video coverage of the event and post-event images (see list of online resources in references), we assume that some parts of the grass cover were compressed by the fragments of icebergs or ice floes washed on shore by the tsunami. In sites where icebergs or ice floes were deposited and melted away, grasses were weighted down and melt-out sediment (gravel, sand, mud) was observed between grass blades. Such spots were surrounded by lush grassy tundra. Tundra was also compressed by tsunami-derived boulders both eroded from beaches and melted out of icebergs (Fig. 3b).

\subsubsection{Coastal erosion}

We recognized two main effects on coastal geomorphology induced by tsunami impact. The tsunami erosion was concentrated on the low bluffs of tundra along the coast between narrow beaches (section of the coast between sites 1, 4, and 5 in Figs. 1c, 2a). Eroded blocks of tundra cover were deposited on land (Fig. 4b). The returning wave caused additional erosion of bluff edges and dissected them by a series of rills/gullies (Fig. 4d). The direction of the wave flow recorded in the orientation of deposited litter, buildings, marine deposits, boulders, and tundra blocks suggests that the wave overwashed the section of settlement through a saddle (site 6 in Fig. 1c) between the middle beach (site 4 in Fig. 1c) and local harbour (site 7 in Fig. 1c) and modified the relief of cliffs in the harbour. The edges of the sedimentary cliffs were gullied, and the steep cliff slopes were spread with eroded blocks of tundra and litter (Fig. 4e). A total of 2 years after the event, normal coastal processes (wave and tidal action) had not yet removed or redistributed the eroded blocks of tundra and litter from the slopes and bases of the cliffs (Fig. 2c).

\subsubsection{Tsunami deposits and boulders}

During the field survey the tsunami deposits were found in two areas located in the direct proximity to small beaches in the central part of the settlement (between sites 4 and 5 in Fig. 1c). Sand and gravel washed from narrow and thin beaches were deposited along the main road (ca. 30-50 m from the shore), where the thickness of deposits exceeds $8-10 \mathrm{~cm}$ (Fig. 5a, b). Thin layers of tsunami deposits (3$5 \mathrm{~cm}$ ), most probably reworked by snowmelt flow (Fig. 5e, f) were found in the saddle (playground area) between sites 4 and 7 (see Fig. 1c). The general scarcity of tsunami deposits can be explained by the geomorphology of the local coastal zone, dominated by sediment-free rocky capes and coves with narrow (7-20 m wide), gravel-dominated beaches (Fig. 2a). Apart from gravel deposits washed from local beaches, waves transported boulders which were found in the inundated terrain in two main types: groups of smaller boulders ( $a$ axis ca. $0.2-0.4 \mathrm{~m}$ ) deposited on marine gravels along the local road and individual larger boulders ( $a$ axis over $1.0 \mathrm{~m}$ ), washed up to $100-120 \mathrm{~m}$ inland between the beach and local harbour (Fig. 5b, f). In a few places we found pads of marine gravels and boulders deposited up to $100 \mathrm{~m}$ from the shore and surrounded by dense grass cover (Fig. 5c, d). Based on the inspection of videos taken during the event, we correlated their location with the deposition of icebergs. In comparison with other Greenlandic coastal sites transformed by a tsunami, i.e. the Paatuut 2000 tsunami (Buchwałet al., 


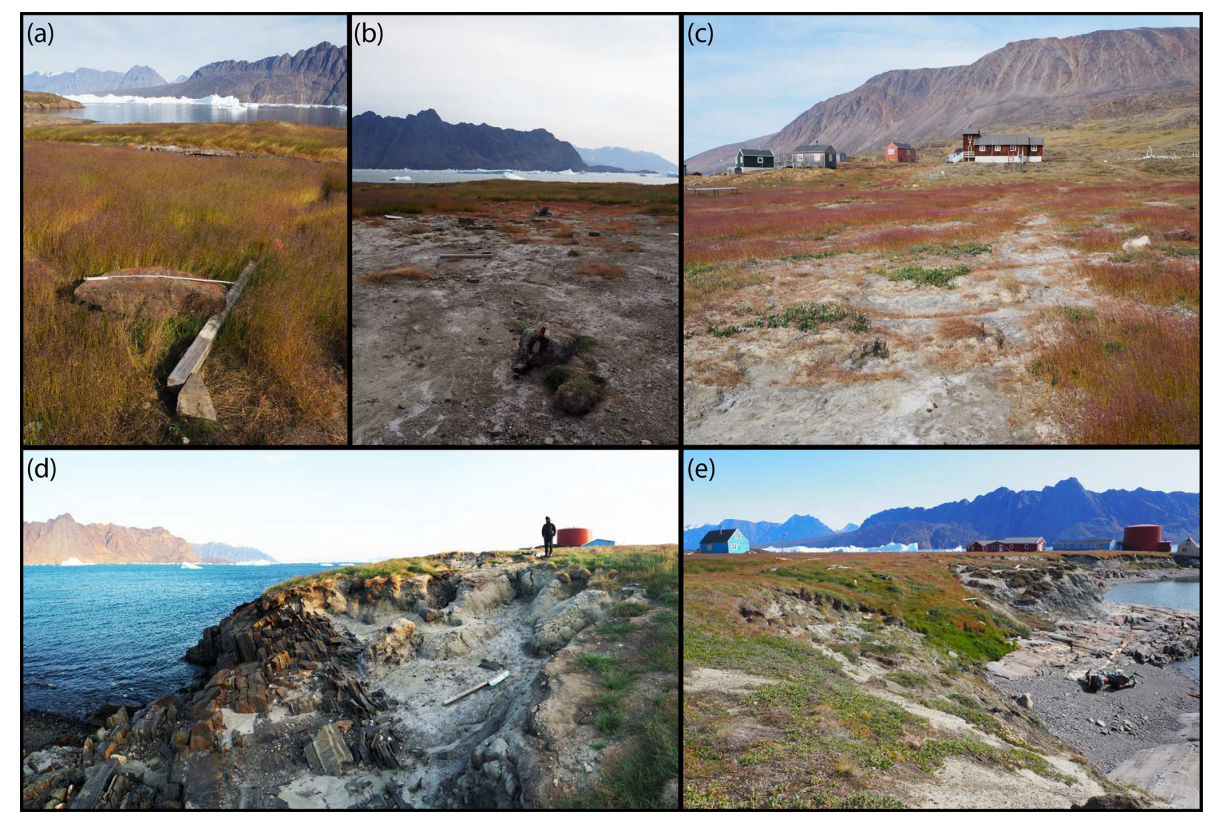

Figure 4. Examples of tsunami effects on tundra and soil covers in Nuugaatsiaq 2 years after the event. (a) High grass covers eroded tundra blocks, boulders, and litter deposited by tsunami; (b) eroded tundra block/raft deposited on the coastal lowland inundated by the tsunami with a thin layer of redistributed marine sediments and salt covers; (c) deposited tundra and soil blocks and gullied ground surface by waves which backwash to the fjord; (d) eroded edges of low bluffs above the small beach (site 4 in Fig. 1c); (e) cliffed coast heavily dissected by tsunami which overwashed the saddle (site 6 in Fig. 1c) between the beach (site 4 in Fig. 1c) and drained to the local harbour (site 7 in Fig. 1c).

2015), the thickness, extent, and diversity of tsunami deposits found in Nuugaatsiaq were much smaller. We attributed this to the sediment-poor beach source and predominantly rocky coastal relief with sediment-free and glacially scoured surfaces. We detected a recognizable difference in tsunami landscape modification between the areas of wave overflow covering most of the saddle in the central part of settlement (site 6 , Fig. 1c) and the area of wave uprush and drainage covering the eastern part of the settlement (terrain between sites 1 and 2, Fig. 1c). In the first zone, the tsunami waves eroded material (sand, gravel, boulders) from the largest beach in the settlement and fragments of sedimentary and tundra bluffs covering rocky coastal slopes (site 4, Fig. 1c) and transported this mixed load of deposits through the settlement to the harbour (site 7, Fig. 1c). This explains the larger number of sites and zones with accumulations of tsunami deposits, signs of tsunami erosion and infrastructure destruction concentrated in this zone. In the second area, tsunami waves approached the rocky coastal zone, almost sediment free, and inundated the grassy lowland carrying mainly community litter and only a small amount of sediment, which was difficult to detect in the lush tundra vegetation inspected 2 years after the event.

It is important to note that the only two sites where terrain changes detected in the field were also traceable in GIS analyses were beach and cliffed coast (Fig. 6) located on the opposite sites of the morphological saddle in the middle of the settlement (sites 4 and 7 in Fig. 1). Other elevation changes detected between two ArcticDEM scenes were attributed to relocation of buildings as coastal landform erosion and subsequent tsunami sediment deposition were too small to be tracked in $2 \mathrm{~m}$ resolution terrain models (Fig. 6).

\subsection{Settlement degradation}

\subsubsection{Infrastructure damage}

Before the tsunami event the Nuugaatsiaq community infrastructure was composed of 94 buildings (houses, service and administration buildings, dog kennels, technical facilities, etc.). The wave destroyed 45 buildings ( $48 \%$ of the original infrastructure): 22 buildings were fully swept away from land, 23 buildings were partly damaged, and 11 were moved between 2 and over $100 \mathrm{~m}$ from the original location (Fig. 7). Most of the buildings were constructed on a wooden frame, covered with wooden boards and settled on pier foundations. Only a few of the settlement buildings were built on a metal frame coated with a corrugated metal sheet settled on a concrete frame foundation. The first type of building (with pier foundations) was not strong enough to resist the wave impact and these structures were pushed by the tsunami or in some cases washed away to the fjord (Fig. 8a, c).

In those buildings which were not moved but still affected by the wave, we observed some damage of their wooden 


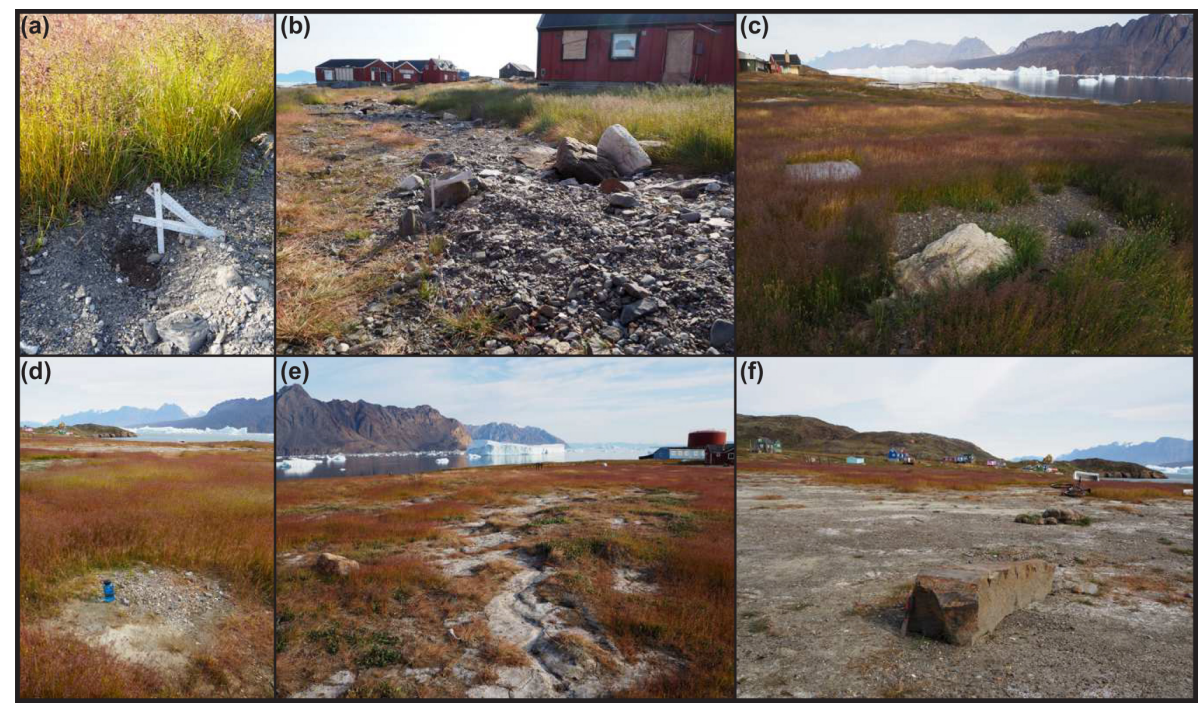

Figure 5. Examples of tsunami deposits preserved in Nuugaatsiaq 2 years after the event. (a) Ca. 4-6 cm thick cover of marine gravels covering grass vegetation. (b) Up to $10 \mathrm{~cm}$ thick layer of tsunami deposits eroded from local beach and deposited on road and grass vegetation. (c) Melt-out material from icebergs (gravels and mud) and ca. $100 \mathrm{~cm}$ long boulder thrown onshore by the tsunami. (d) Deposits melted out from an iceberg washed on shore by waves; (e) rills eroded in soil and tsunami deposits by returning wave. (f) Over $100 \mathrm{~cm}$ long boulder moved by waves on the thin layer of gravels and eroded soil deposits. Note salty surfaces and eroded tundra rafts in the background.

cladding, as well as a deposition of marine sediments and litter in the ground-floor area. The typical damages observed in buildings which were pushed by the tsunami but remained on land were broken windows and doors and devastated interior. In contrast to buildings with pier foundations, much less damage was observed in buildings with concrete frame foundations. These, due to a more stable anchoring in the ground, gave a much higher resistance to the wave impact. The most common damage included broken walls and bowed and twisted metal construction frames (Fig. 8b, d). It should be considered extremely fortunate that the fuel tanks situated at the power plant (which were one of the first parts of infrastructure hit by tsunami) were not destroyed and no leakage of petrol was reported (Fig. 8b).

\subsubsection{Assessment of social, economic, and environmental impacts of tsunami in Nuugaatsiaq}

The Karrat fjord tsunami, which hit the Nuugaatsiaq settlement in 2017, was the first event which had such a devastating effect on an inhabited Arctic settlement, in terms of both landscape modification and infrastructure damage. Previous waves known from the cold and glaciated regions such as Alaskan Lituya (1958) and Taan (2015) flooded unpopulated and remote areas. In Greenland, the Paatuut tsunami (2000) damaged the infrastructure of Qullissat; however in this case, due to the earlier closure of the coal mine (1972) the settlement was already abandoned years before the event. Therefore, this was the first time an assessment of the social and economic effects of a tsunami in this region was possible. (Table 1).
The financial data from the Government of Greenland (Naalakkersuisut) documents (Forslag til TILLÆGSBEVILLINGSLOV for 2017, from August 2018) show the costs associated with the relocation of tsunami victims of DKK 14877000.00 (ca. USD 248 085.00, 15 May 2020), which can be treated as a rough estimate of an economic cost of the event. The document also declares a one-off payment to tsunami victims amounting to DKK 50000 (USD 7548.00, 15 May 2020). In our opinion the total economic cost was significantly higher as the total market value of 45 destroyed settlement infrastructure objects (incl. buildings) was not included in the reports. Nevertheless, the settlement remains abandoned to this day and the threat of another tsunami wave remains active (Fritz et al., 2018; Paris et al., 2019). Apart from the tragedy of four fatalities, nine wounded inhabitants, and countless dog deaths, the catastrophe still has its social repercussions. Thirty-nine people were evacuated and separated into the settlements of Uummannaq and Qaarsut. The displaced have lost their life's work, their hunting area, sentimental value of their homes, and social bonds. In their new villages more expensive rent, isolation, and adaptation difficulties often await them

From the perspective of environmental protection and coastal management, the remaining material and waste in the settlement area still constitute a serious hazard. Despite the considerable effort from the local government to secure the site through reinforcement of damaged constructions, pumping fuel out of the tanks, and the removal of batteries and engines from machines and vehicles, we mapped significant amounts of waste (Fig. 8e-g). We found broken pieces 
Table 1. Summary of tsunami effects on coastal landscape and the Nuugaatsiaq community and recommended hazard risk reduction actions.

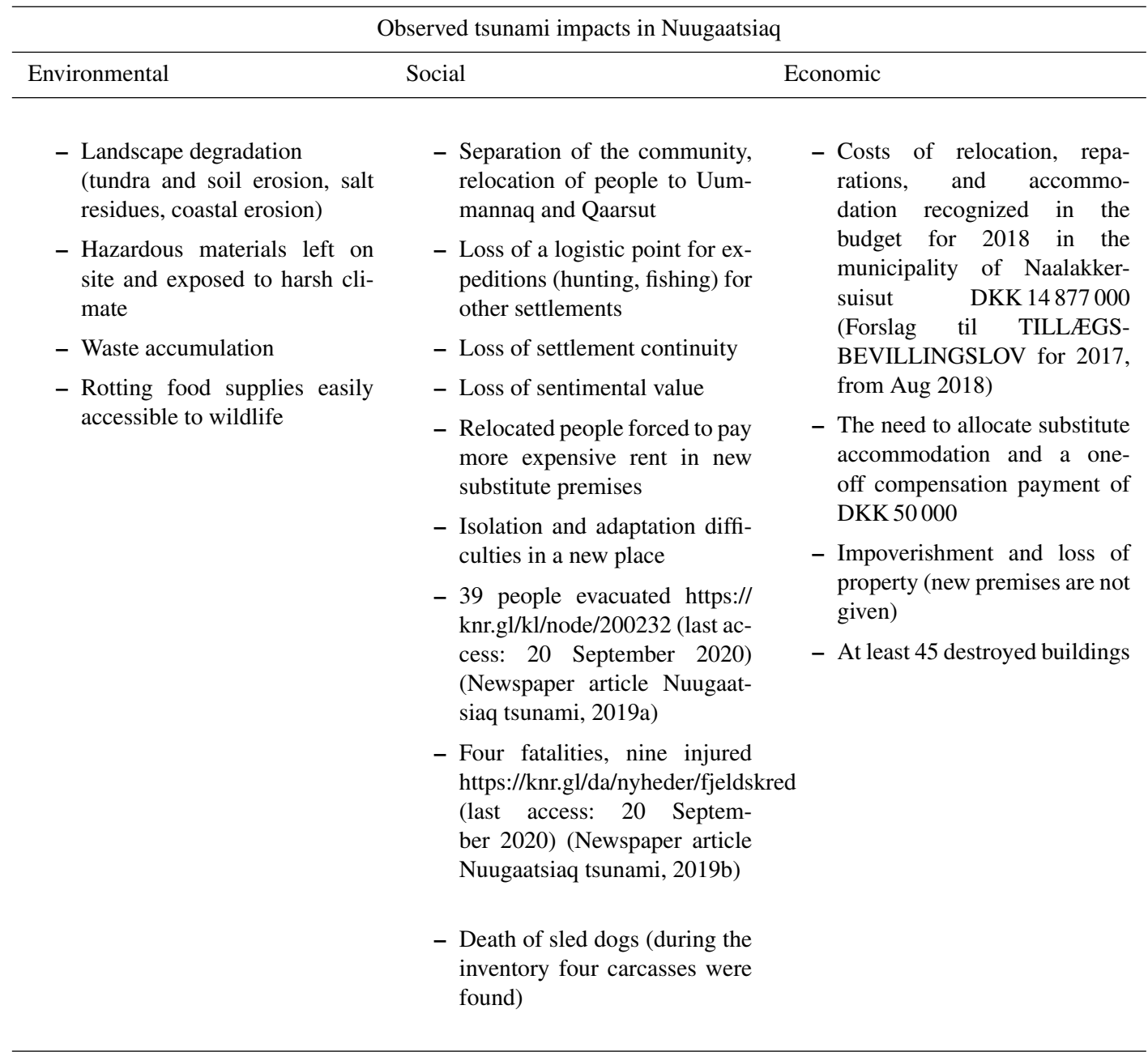

Future risk reduction actions in Arctic coastal communities

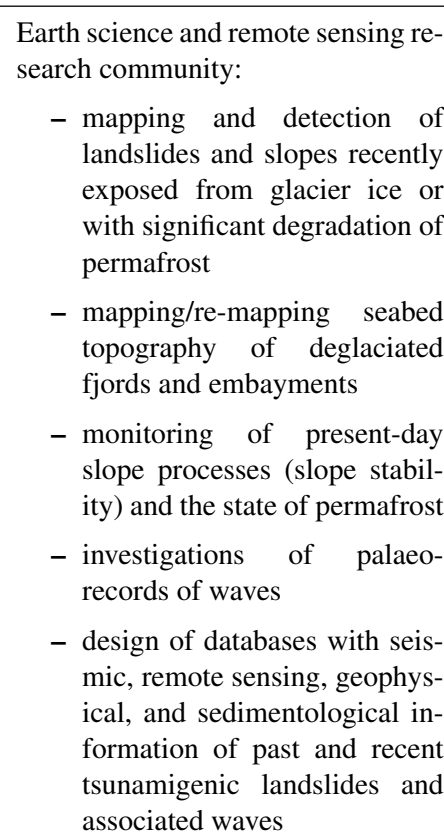




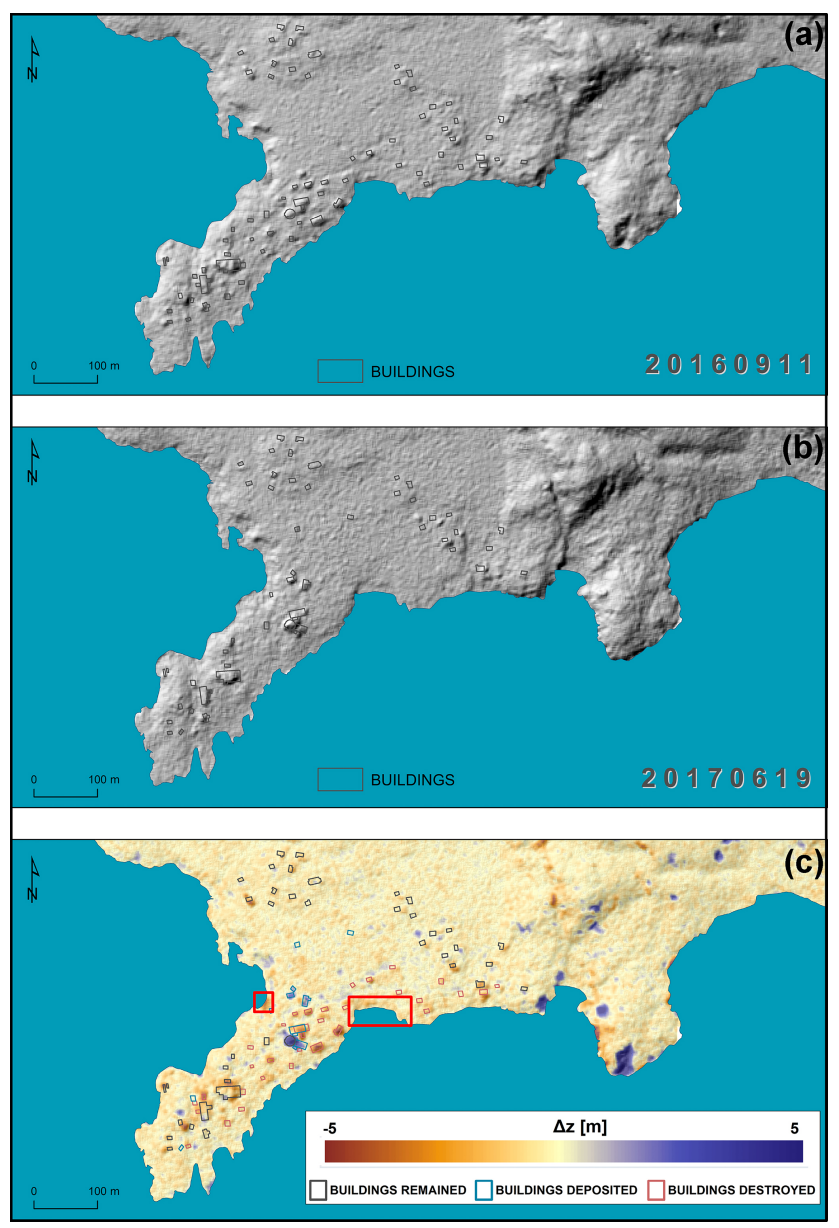

Figure 6. Post-tsunami terrain change in the Nuugaatsiaq area. (a) DTM of study site on 11 September 2016 - pre-tsunami conditions. (b) DTM of study site on 19 September 2017 - post-tsunami conditions. (c) Terrain change calculated from data of two digital terrain models (DTM). The colour scale illustrates values of terrain change $(\Delta z)$, where warm colours stand for an elevation decrease due to erosion, and cold colours represent an elevation increase led by the effects of deposition. Please notice that major changes in the terrain are associated with construction, destruction, or relocation of buildings. The resolution of the model $(2 \mathrm{~m})$ precluded detection of small-scale landscape modifications observed during the fieldwork. Two sites where both field observations and remote sensing analyses detected significant change (erosion) were the beach (site 4 in Fig. 1) and cliff edge in the harbour (site 7 in Fig. 1) on the opposite sides of the saddle (marked by red rectangles).

of electronic equipment, ammunition, rotting food supplies, bags with faecal matter, sled dog carcasses, and other municipal waste which had not been disposed of from the settlement before and after the event (Fig. 8). In Nuugaatsiaq plastic litter is widespread not only along narrow beaches (already mixed with beach sediments), but also spread along the main road of the settlement and around the overwashed saddle between the southern coast and the harbour, and subject to further transport by strong winds (Fig. 8). Plastic
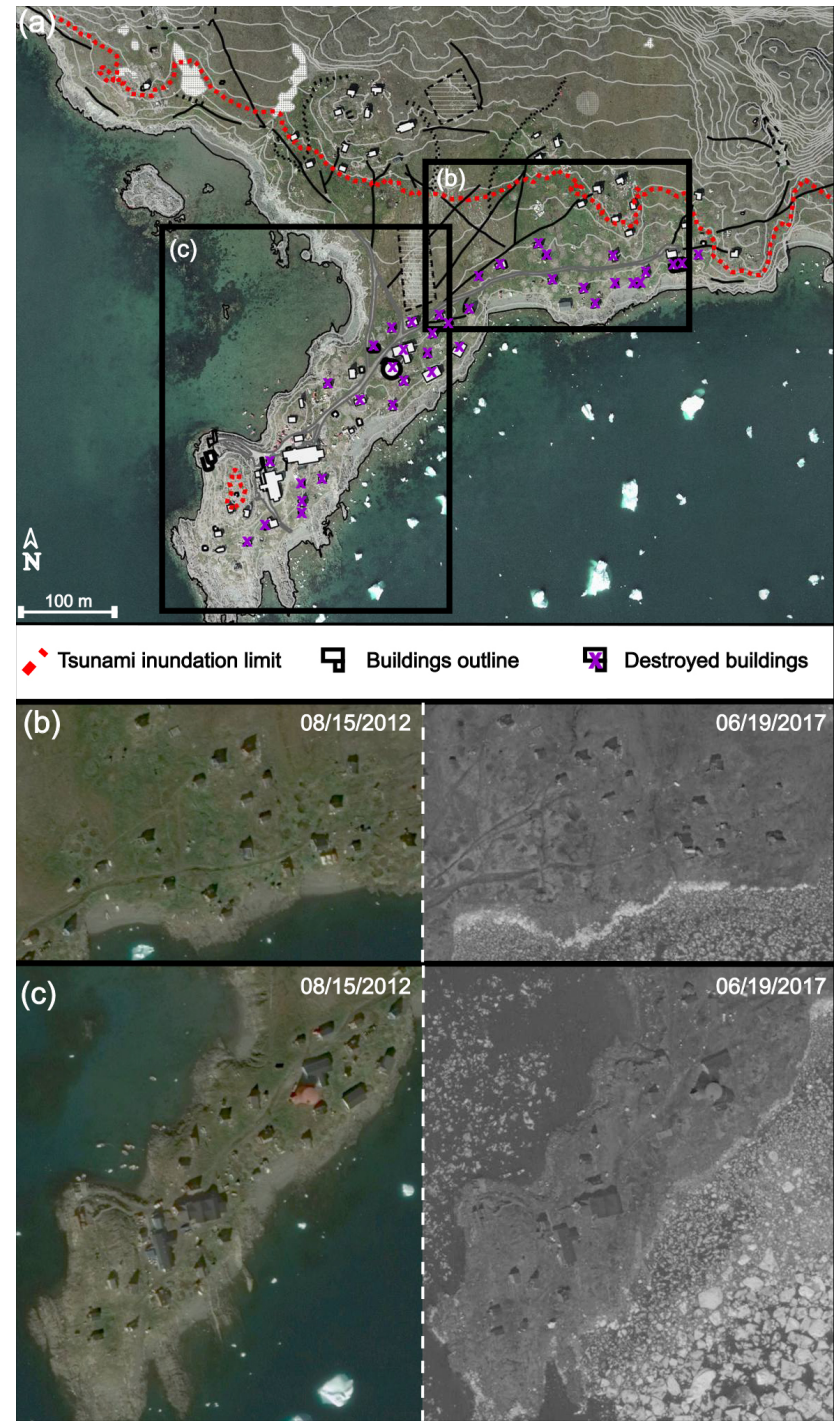

Figure 7. Scale of destruction in settlement infrastructure. (a) General overview of area inundated by the tsunami with location of damaged buildings. The inventory of tsunami-induced changes of settlement infrastructure is based on interception of aerial images, local spatial plans, and field surveying. Background orthophoto and topographic map: nunagis.gl. (b) Satellite image of settlement before the tsunami impact (15 August 2012) and (c) satellite image of settlement after the tsunami impact illustrate the scale of destruction and dislocation of buildings (19 June 2017). Background Google Earth Image (C) 2020 Maxar Technologies.

waste is a serious problem of Arctic coastal environments, and the Nuugaatsiaq case is unfortunately another contributor to this type of environmental pollution (e.g. Cózar et al., 2017; Bergmann et al., 2017; Jaskólski et al., 2018). After the evacuation of Nuugaatsiaq the disposal of waste and better securing of damaged infrastructure at the site have been hindered by the existing high risk of another tsunamigenic landslide in Karrat Fjord (Paris et al., 2019). 


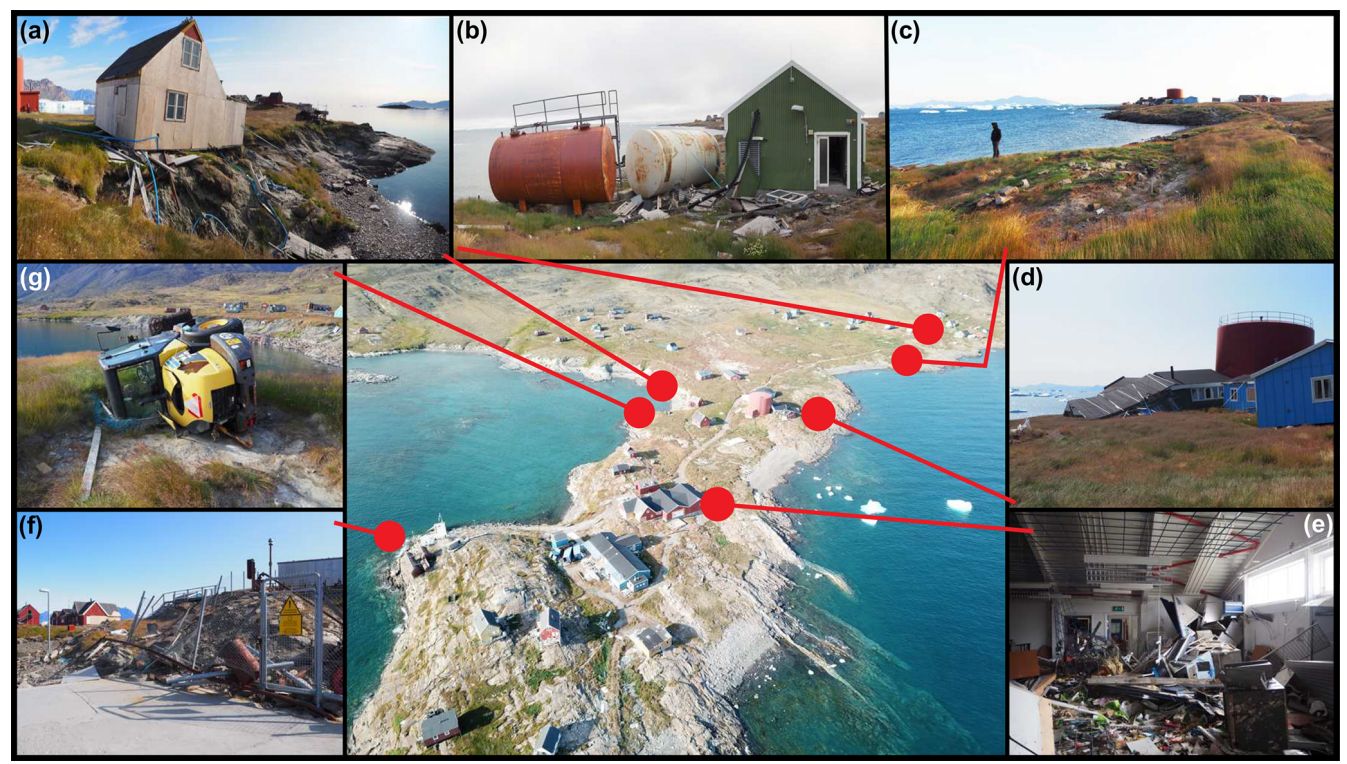

Figure 8. Examples of infrastructure damage caused by the 2017 tsunami in Nuugaatsiaq. (a) Wooden house removed by wave from point foundation transported several dozens of metres. (b) Fuel tanks washed away from concrete frames and pushed towards power plant. Note large accumulation of litter and tsunami deposits around and inside the buildings; (c) site of former building position, which was destroyed and swept away by the tsunami. Note broken wooden point foundations, media connections, and erosional gullies. (d) Smashed and collapsed wooden school building moved towards major water tank. (e) Interior of local shopping centre passed by tsunami. Note large amounts of litter and rotting food supplies and twisted and bowed metal frame construction. (f) Partly torn metal fence around fuel storage site which acted as a trap for litter transported by tsunami; (g) example of heavy machine knocked over by waves.

\subsection{Arctic coastal communities threatened by tsunamis - rising risk and rising awareness}

One of the most evident effects of Arctic climate warming is the increased activity of geohazard processes along the circum-Arctic coasts (e.g. Fritz et al., 2017). The majority of these processes pose a significant threat to Arctic coastal communities and built infrastructure (e.g. Forbes et al., 2011; Hatcher and Forbes 2015; Radosavljevic et al., 2016; Jaskólski et al., 2018). Most of the recent Arctic coastal change studies concentrated on accelerated coastal erosion rates in locations spread across the Arctic region and associated them with diminishing sea-ice extent, longer exposure to storm wave impacts, and thawing coastal permafrost (e.g. Overduin et al., 2014; Farquharson et al., 2018; Irrgang et al., 2018; Isaev et al., 2019). Also, in glaciated parts of the Arctic, such as Greenland or Svalbard, coastal research focused on the response of coastal zone to increased delivery of glacial sediments (e.g. Bendixen et al., 2017; Strzelecki et al., 2018) or rocky coast interaction with coastal permafrost (e.g. Strzelecki et al., 2017; Lim et al., 2020). At the same time little attention was paid to cold-region tsunami hazards whose effects are devastating to both human and natural coastal environments. The recent examples of tsunamis in Alaska (Taan, 2015) and Greenland (Paatuut, 2000; Karrat, 2017) demonstrate how severe impacts on coastal environments and communities can be. It is important to note that with continued warming (favouring permafrost thaw, glacier retreat, or extreme meteorological phenomena), such tsunamigenic landslides are likely to be far more frequent (Gosse et al., 2019).

To put it into a Greenlandic perspective, the recent mapping of potential tsunamigenic landslides performed by Svennevig (2019) indicated 564 landslides just between Sigguup Nunaa and Qeqertarsuaq in West Greenland (ca. $230 \mathrm{~km}$ in a straight line). Benjamin et al. (2018) mapped 20 rock avalanches just along one short section (ca. $25 \mathrm{~km}$ ) of the southern coast of Nuussuaq Peninsula in direct proximity of Sullorsuaq Strait (similar avalanche triggered the Paatuut tsunami in 2000). Svennevig et al. (2019) demonstrated that the area around the Karrat Fjord landslide has continued to be active, and another tsunamigenic landslide is highly probable.

Although beyond the scope of this study, here it is important to mention another type of extreme phenomenon impacting the Greenlandic coastal zone - waves triggered by iceberg-roll events that are powerful enough to erode local beaches and wash away coastal infrastructure (Long et al., 2018). Calving of Greenlandic glaciers also produces extreme waves that are able to erode glacial landforms and lead to substantial degradation of coastal landscape (e.g. Lüthi and Vieli, 2016). It is important to note that with continued temperature warming in the Arctic, such landslides, glacier calving, and iceberg rollover events are projected to be far 
more common and have profound effects on the functioning of coastal communities and landscapes.

\section{Conclusions}

In the present study an attempt has been made to evaluate the impact of the 17 June 2017 tsunami wave on the Nuugaatsiaq settlement infrastructure and coastal landscape using a combination of field-based geomorphological mapping, spatial planning, and GIS analyses. Based on the present investigation, the following conclusions have been reached.

The Karrat Fjord event is the first known example of an Arctic tsunami which directly impacted an inhabited Arctic settlement and forced its evacuation.

The scale of tsunami damage, including destruction of $48 \%$ of settlement community infrastructure and a high risk of another event, prevents the community from returning to the settlement.

Apart from housing facilities, three waves destroyed most public service buildings, e.g. school, power plant, shopping centre, administration centre, and seafood processing plant.

Among the waste accumulations left in the area are electronic equipment, rotting food supplies, faecal matter, sled dog carcasses, and ammunition and a lot of municipal waste, including a large quantity of plastic. Most of the waste is completely unprotected and exposed to weather conditions and wildlife.

Although the tsunami inundated terrain up to $9 \mathrm{~m}$ a.s.l.the geomorphological effects of the tsunami were less pronounced than in previously described examples of cold region tsunami impacts (Lituya, 1958; Paatuut, 2000; Taan, 2015), which can be explained by the local coastal morphology and geology (rock-dominated coasts with small and sediment-poor beaches) and relatively low wave heights (1$1.5 \mathrm{~m})$.

Mapped tsunami deposits included gravel-dominated beach sediments, boulders, and ice-rafted material derived from icebergs stranded on land.

Around 2 years after the event the effects of tsunami erosion were still detectable on the surface of local roads and edges of sedimentary cliffs along the harbour.

Data availability. Data in this paper can be made available for scientific use upon request to the authors.

Author contributions. MCS and MJW designed the study and carried out fieldwork. MWJ analysed the aerial imagery and settlement spatial plan data. MCS guided the intellectual direction of the research. Both authors wrote the manuscript.

Competing interests. The authors declare that they have no conflict of interest.
Acknowledgements. This paper is dedicated to the Nuugaatsiaq community, who suffered during this dramatic event. Mateusz C. Strzelecki wrote a paper as a NAWA Bekker Programme Fellow (PPN/BEK/2018/1/00306) at Alfred Wegener Institute in Potsdam. Marek W. Jaskólski wrote this paper as a NAWA Iwanowska Programme Fellow (PPN/IWA/2018/1/00078) at Leibniz Institute of Ecological Urban and Regional Development in Dresden. Justyna Dudek is thanked for help with DTM algebra and detection of posttsunami terrain changes in ArcGIS. Ryszard Szopa is thanked for post-fieldwork discussions and language corrections. We thank reviewers Don Forbes and Dan Shugar and Mauricio González for critically reading the manuscript and suggesting substantial improvements. This paper is a contribution to the National Science Centre grant no. 2018/29/N/ST10/01947: GROZA - Impact of climate-induced geohazards on Greenlandic coastal environments - case study of Disko Bay, Western Greenland, awarded to Marek W. Jaskólski.

Financial support. This research has been supported by the National Science Centre grant no. 2018/29/N/ST10/01947.

The publication of this article was funded by the Open Access Fund of the Leibniz Association.

Review statement. This paper was edited by Mauricio Gonzalez and reviewed by Donald L. Forbes and Dan Shugar.

\section{References}

Bay, C.: Floristic division and vegetation zonation ofGreenland in relevance to a circumpolar arcticvegetation map: 27-31, in: Proceedings of the Second Circumpolar Arctic Vegetation Mapping Workshop,Arendal, Norway, 19-24 May 1996, edited by: Walker, S. and Lillie, A. C., Occasional Paper No. 52, Institute of Arctic and Alpine Research, University of Colorado, 1997.

Bendixen, M., Lønsmann Iversen, L., Anker Bjørk, A., Elberling, B., Westergaard-Nielsen, A., Overeem, I., Barnhart, K. R., Abbas Khan, S., Box, J. E., Abermann, J., Langley, K., and Kroon, A.: Delta progradation in Greenland driven by increasing glacial mass loss, Nature, 550, 101, https://doi.org/10.1038/nature23873, 2017.

Benjamin, J., Rosser, N. J., Dunning, S. A., Hardy, R. J., Kelfoun, K., and Szczuciński, W.: Transferability of a calibrated numerical model of rock avalanche run-out: Application to 20 rock avalanches on the Nuussuaq Peninsula, West Greenland, Earth Surf. Process. Landf., 43, 3057-3073, https://doi.org/10.1002/esp.4469, 2018.

Bergmann, M., Lutz, B., Tekman, M. B., and Gutow, L. : Citizen scientists reveal: Marine litter pollutes Arctic beaches and affects wild life, Mar. Pollut. Bull., 125, 535-540, 2017.

Bessette-Kirton, E., Allstadt, K., Pursley, J., and Godt, J.: Preliminary analysis of satellite imagery and seismic observations of the Nuugaatsiaq Landslide and Tsunami, Greenland, U.S. Geological Survey - Landslide Hazards Program, available at: https://landslides.usgs.gov/research/featured/ 2017-nuugaatsiaq/ (last access: 11 October 2019), 2017. 
Bloom, C. K., MacInnes, B., Higman, B., Shugar, D. H., Venditti, J. G., Richmond, B., and Bilderback, E. L.: Catastrophic landscape modification from a massive landslide tsunami in Taan Fiord, Alaska, Geomorphology, 353, 107029, https://doi.org/10.1016/j.geomorph.2019.107029, 2020.

Buchwał, A. S., Szczuciński, W., Strzelecki, M. C., Long, A. J.: New insights into the 21 November 2000 tsunami in West Greenland from analyses of the tree-ring structure of Salix glauca, Pol. Polar Res., 36, 51-65, https://doi.org/10.1515/popore-20150005, 2015.

Butler, R.: Seismic precursors to a 2017 Nuugaatsiaq, Greenland, earthquake-landslide-tsunami event, Nat. Hazards, 96, 961-973, https://doi.org/10.1007/s11069-019-03582-8, 2019.

Chao, W. A., Wu, T. R., Ma, K. F., Kuo, Y. T., Wu, Y. M., Zhao, L., Chung, M. J., Wu, H., and Tsai, Y. L.: The Large Greenland Landslide of 2017: Was a Tsunami Warning Possible?, Seismol. Res. Lett., 89, 1335-1344, https://doi.org/10.1785/0220170160, 2018.

Christiansen, H. H. and Humlum, O.: Permafrost, in: Topografisk Atlas Grønland, Det Kongelige Danske Geografiske Selskab og Kort \& Matrikelstyrelsen, edited by: Jakobsen, B. H., Bôcher, J., Nielsen, N., Guttesen, R., Humlum, O., and Jensen, E., 2000.

Clinton, J., Larsen, T., Dahl-Jensen, T., Voss, P., and Nettles, M.: Seismic observations from Nuugatsiaq slide/tsunami, available at: https://ds.iris.edu/ds/nodes/dmc/specialevents/2017/06/ 22/nuugaatsiaq-greenland-landslideand-tsunami/, last access: 5 July 2017.

Cózar, A., Martí, E., Duarte, C. M., García-de-Lomas, J., van Sebille, E., Ballatore, T. J., Eguíluz, V. M., González-Gordillo, J. I., Pedrotti, M. L. ,Echevarría, F., Troublè, R., and Irigoien, X.: The Arctic Ocean as a dead end for floating plastics in the North Atlantic branch of the Thermohaline Circulation, Sci. Adv., 3, e1600582, https://doi.org/10.1126/sciadv.1600582, 2017.

Dahl-Jensen, T., Larsen, L. M., Pedersen, S. A. S., Pedersen, J., Jepsen, H. F., Pedersen, G., Nielsen, T., Pedersen, A. K., Von Platen-Hallermund, F., and Weng, W.: Landslide and Tsunami 21 November 2000 in Paatuut, West Greenland, Nat. Hazards, 31, 277-287, https://doi.org/10.1023/b:Nhaz.0000020264.70048.95, 2004.

Dowdeswell, J. A., Hogan, K. A., and Cofaigh, C.Ó.: Submarine glacial-landform distribution across the West Greenland margin: a fjord-shelf-slope transect through the Uummannaq system (70-718 N), Geological Society, London, Memoirs, 46, 453460, 2016.

Dufresne, A., Geertsema, M., Shugar, D. H., Koppes, M., Higman, B., Haeussler, P. J., Stark, C., Venditti, J. G., Bonno, D., Larsen, C., Gulick, S. P. S., McCall, N., Walton, M., Loso, M. G., and Willis, M. J.: Sedimentology and geomorphology of a large tsunamigenic landslide, Taan Fiord, Alaska, Sed. Geol., 364, 302-318, https://doi.org/10.1016/j.sedgeo.2017.10.004, 2018.

Farquharson, L. M., Mann, D. H., Swanson, D. K., Jones, B. M., Buzard, R. M., and Jordan, J. W.: Temporal and spatial variability in coastline response to declining sea-ice in northwest Alaska, Mar. Geol., 404, 71-83, https://doi.org/10.1016/j.margeo.2018.07.007, 2018.

Financial document: Forslag til TILLÆGSBEVILLINGSLOV for 2017, from 2018/8, available at: https://naalakkersuisut.gl/ / media/Nanoq/Files/AttachedFiles/Finans/DK/Finanslov/2019/
Forslagtiltill\{ \ae\}gsbevillingslov2017-DK-tiltryk-tilrettet.pdf, last access: 8 November 2019.

Forbes, D. L.: State of the Arctic Coast 2010 - Scientific Review and Outlook, International Arctic Science Committee, LandOcean Interactions in the Coastal Zone, Arctic Monitoring and Assessment Programme, International Permafrost Association, Helmholtz-Zentrum, Geesthacht, Germany, 178, 2011.

Fritz, M., Vonk, J. E., and Lantuit, H.: Collapsing Arctic coastlines, Nat. Clim. Change, 7, 6, https://doi.org/10.1038/nclimate3188, 2017.

Fritz, H. M., Giachetti, T., Anderson, S., and Gauthier, D.: Field survey of the 17 June 2017 landslide generated Tsunami in Karrat Fjord, Greenland. Geophyscial Research Abstracts, 20, EGU2018-18345, 2018, edited by: Gauthier, D., Anderson, S. A., Fritz, H. M., and Giachetti, T.: Karrat Fjord (Greenland) tsunamigenic landslide of 17 June 2017: initial 3D observations, Landslides, 15, 327-332, https://doi.org/10.1007/s10346-017-0926-4, 2018.

Gauthier, D., Anderson, S. A., Fritz, H. M., and Giachetti, T.: Karrat Fjord (Greenland) tsunamigenic landslide of 17 June 2017: initial 3D observations, Landslides, 15, 327-332, https://doi.org/10.1007/s10346-017-0926-4, 2018.

Gosse, J. C., Tremblay, T., Broom, L. A., Campbell, D. C., Wenzel, G., Nedimoviæ, M. R., and Forget Brisson, L.: Initial results from the ULINNIQ seismicity and tsunami hazard project, northeastern Baffin Island, Nunavut; in Summary of Activities 2019, Canada-Nunavut Geoscience Office, 101-124, 2019.

Haeussler, P. J., Gulick, S. P. S., McCall, N., Walton, M., Reece, R., Larsen, C., Shugar, D. H., Geertsema, M., and Venditti, J. G.: Submarine deposition of a subaerial landslide in Taan Fiord, Alaska, J. Geophys. Res.-Earth Surf., 123, 2443-2463, https://doi.org/10.1029/2018JF004608, 2018.

Harbitz, C. B., Glimsdal, S., Løvholt, F., Kveldsvik, V., Pedersen, G. K., and Jensen, A.: Rockslide tsunamis in complex fjords: From an unstable rock slope at Åkerneset to tsunami risk in western Norway, Coast. Eng., 88, 101-122, https://doi.org/10.1016/j.coastaleng.2014.02.003, 2014.

Hatcher, S. V. and Forbes, D.: Exposure to Coastal Hazards in a Rapidly Expanding Northern Urban Centre, Iqaluit, Nunavut, Arctic, 68, 453-471, https://doi.org/10.14430/arctic4526, 2015.

Higman, B., Shugar, D. H., Stark, C. P., Ekstrom, G., Koppes, M. N., Lynett, P., Dufresne, A., Haeussler, P. J., Geertsema, M., Gulick, S., Mattox, A., Venditti, J. G., Walton, M. A. L., McCall, N., McKittrick, E., MacInnes, B., Bilderback, E. L., Tang, H., Willis, M. J., Richmond, B., Reece, R. S., Larsen, C., Olson, B., Capra, J., Ayca, A., Bloom, C., Williams, H., Bonno, D., Weiss, R., Keen, A., Skanavis, V., and Loso, M.: The 2015 landslide and tsunami in Taan Fiord, Alaska, Sci. Rep., 8, 12993, https://doi.org/10.1038/s41598-018-30475-w, 2018.

Irrgang, A. M., Lantuit, H., Manson, G. K., Günther, F., Grosse, G., and Overduin, P. P.: Variability in Rates of Coastal Change Along the Yukon Coast, 1951 to 2015, J. Geophys. Res.-Earth Surf., 123, 779-800, https://doi.org/10.1002/2017jf004326, 2018.

Isaev, V. S., Koshurnikov, A. V., Pogorelov, A., Amangurov, R. M., Podchasov, O., Sergeev, D. O., Buldovich, S. N., Aleksyutina, D. M., Grishakina, E. A., and Kioka, A.: Cliff retreat of permafrost coast in south-west Baydaratskaya Bay, Kara Sea, during 2005-2016, Permafr. Perigl. Process., 30, 35-47, https://doi.org/10.1002/ppp.1993, 2019. 
Jaskólski, M. W., Pawłowski, Ł., and Strzelecki, M. C.: High Arctic coasts at risk - the case study of coastal zone development and degradation associated with climate changes and multidirectional human impacts in Longyearbyen (Adventfjorden, Svalbard), Land Degrad. Dev., 29, 2514-2524, https://doi.org/10.1002/ldr.2974, 2018.

Jaskólski M., Pawłowski Ł., Strzelecki M., Zagórski P., Lane T. P.: Trash on Arctic beach - case study of coastal pollution along Calypsostranda, Bellsund, Svalbard, Pol. Polar Res., 39, 211-224, 2018.

Lane, T. P., Roberts, D. H.,Ó Cofaigh, C., Rea, B. R., and Vieli, A.: Glacial landscape evolution in the Uummannaq region, West Greenland, Boreas, 45, 220-234, https://doi.org/10.1111/bor.12150, 2016.

Lim, M., Strzelecki, M. C., Kasprzak, M., Swiard, Z. M., Webster, C. , Woodward, J., and Gjetlen, H.: Arctic rock coast responses under a changing climate. Remote Sens. Environ., 236, 111500, https://doi.org/10.1016/j.rse.2019.111500, 2020.

Lepping, O. and Daniëls, F. J. A.: Phytosociology of Beach and Salt Marsh Vegetation in Northern West Greenland, Polarforschung, 76, 95-108, 2007.

Long, A. J., Szczuciński, W., and Lawrence, T.: Sedimentary evidence for a mid-Holocene iceberg-generated tsunami in a coastal lake, west Greenland, Arktos, 1, 6, https://doi.org/10.1007/s41063-015-0007-7, 2015.

Lüthi, M. P. and Vieli, A.: Multi-method observation and analysis of a tsunami caused by glacier calving, The Cryosphere, 10, 9951002, https://doi.org/10.5194/tc-10-995-2016, 2016.

Madsen, J.C.: Udsteder og bopladser i Grønland 1901-2000, Atuagkat, 160-164, 2009.

Miller, D. J.: The Alaska earthquake of July 10, 1958: Giant wave in Lituya Bay, B. Seismol. Soc. Am., 50, 253-266, 1960.

Mott, A. V., Bird, D. K., Grove, M., Rose, N., Bernstein, S., Mackay, H., and Krebs, J.: Karrat Isfjord: A newly discovered Paleoproterozoic carbonatite-sourced REE deposit, central West Greenland, Econom. Geol., 108, 1471-1488, https://doi.org/10.2113/econgeo.108.6.1471, 2013.

Newspaper article Nuugaatsiaq tsunami: 39 evakueret fra Nuugaatsiaq, available at: https://knr.gl/kl/node/200232, last access: 8 November 2019a.

Newspaper article Nuugaatsiaq tsunami: Arctic Command: Landslide in Karrat Isfjorden due to tidal wavem available at: https: //knr.gl/da/nyheder/fjeldskred-i-karrat-isfjorden-skyld-i-flodbl T1 lolge, last access: 8 November $2019 \mathrm{~b}$.

Obu, J., Westermann, S., Bartsch, A., Berdnikov, N., Christiansen, H. H., Dashtseren, A., Delaloye, R., Elberling, B., Etzelmüller, B., and Kholodov , A.: Northern hemisphere permafrost map based on TTOP modelling for 2000-2016 at $1 \mathrm{~km} 2$ scale, EarthSci. Rev., 193, 299-316, 2019.

Overduin, P. P., Strzelecki, M. C., Grigoriev, M. N., Couture, N., Lantuit, H., St-Hilaire-Gravel, D., Günther, F., and Wetterich, S.: Coastal changes in the Arctic., in: Sedimentary Coastal Zones from High to Low Latitudes: Similarities and Differences, edited by: Martini, I. P. and Wanless, H. R., Geological Society, London, Special Publications 388, 103-129, 2014.

Paris, A., Okal, E. A., Guérin, C., Heinrich, P., Schindelé, F., and Hébert, H.: Numerical Modeling of the June 17, 2017 Landslide and Tsunami Events in Karrat Fjord, West Greenland, Pure Appl.
Geophys., 176, 3035-3057, https://doi.org/10.1007/s00024-01902123-5, 2019.

Pedersen, S. A. S., Dahl-Jensen, T., Jepsen, H. F., Pedersen, G. K., Nielsen, T., Pedersen, A. K., von Platen-Hallermund, F., and Weng, W.: Tsunami-generating rock fall and landslide on the south coast of Nuussuaq, central West Greenland, Geol. Greenland Surv. Bull., 191, 73-83, 2002.

Poli, P.: Creep and slip: Seismic precursors to the Nuugaatsiaq landslide (Greenland), Geophys. Res. Lett., 44, 8832-8836, https://doi.org/10.1002/2017gl075039, 2017.

Porter, C., Morin, P., Howat, I., Noh, M.-J., Bates, B., Peterman, K., Keesey, S., and Bojesen, M.: ArcticDEM, https://doi.org/10.7910/DVN/OHHUKH, Harvard Dataverse, V1, [06.08.2020], 2018.

Radosavljevic, B., Lantuit, H., Pollard, W., Overduin, P., Couture, N., Sachs, T., Helm, V., and Fritz, M.: Erosion and Flooding Threats to Coastal Infrastructure in the Arctic: A Case Study from Herschel Island, Yukon Territory, Canada, Estuar.Coasts, 39, 900-915, https://doi.org/10.1007/s12237-015-0046-0, 2016.

Recon trip report After recon trip, researchers say Greenland tsunami in June reached 300 feet high, available at: , last access: 8 November 2019.

Rignot, E., Fenty, I., Xu, Y., Cai, C., Velicogna, I., Ó Cofaigh, C., Dowdeswell, J. A., Weinrebe, W., Catania, G., and Duncan, D.: Bathymetry data reveal glaciers vulnerable to ice-ocean interaction in Uummannaq and Vaigat glacial fjords, west Greenland, Geophys. Res. Lett., 43, 2667-2674, https://doi.org/10.1002/2016GL067832, 2016.

Roberts, D. H., Rea, B. R., Lane, T. P., Schnabel, C., and Rodes, A.: New constraints on Greenland ice sheet dynamics during thelast glacial cycle: evidence from the Uummannaq ice stream system, J. Geophys. Res.-Earth Surf., 118, 519-541, https://doi.org/10.1002/jgrf.20032, 2013.

Schiermeier, Q.: Huge landslide triggered rare Greenland megatsunami, Nature, News, https://doi.org/10.1038/nature.2017.22374, 2017.

Sørensen, E. V. and Guarnieri, P.: Remote geological mapping using 3D photogrammetry: an example from Karrat, West Greenland, Geol. Surv. Denmark Greenl. Bull., 41, 63-66, 2018.

Strzelecki, M. C., Kasprzak, M., Lim, M., Swirad, Z. M., Jaskólski, M., Pawłowski, Ł., and Modzel, P.: Cryo-conditioned rocky coast systems: A case study from Wilczekodden, Svalbard, Scie. Total Environ., 607-608, 443-453, https://doi.org/10.1016/j.scitotenv.2017.07.009, 2017.

Strzelecki, M. C., Long, A. J., Lloyd, J. M., Małecki, J., Zagórski, P., Pawłowski, Ł., and Jaskólski, M. W.: The role of rapid glacier retreat and landscape transformation in controlling the post-Little Ice Age evolution of paraglacial coasts in central Spitsbergen (Billefjorden, Svalbard), Land Degr. Develop., 29, 1962-1978, https://doi.org/10.1002/ldr.2923, 2018.

Svennevig, K.: Preliminary landslide mapping in Greenland, Geological Survey of Denmark and Greenland Bulletin, 43, e2019430207, https://doi.org/10.34194/GEUSB-201943-02-07, 2019.

Svennevig, K., Solgaard, A. M., Salehi, S., Dahl-Jensen, T., Merryman Boncori, J. P., Larsen, T. B., and Voss, P. H.: A multidisciplinary approach to landslide monitoring in the Arctic: Case study of the March 2018 ML 1.9 seismic event near the Karrat 2017 landslide, Geological Survey of Denmark and Greenland 
Bulletin, 43, e2019430208, https://doi.org/10.34194/GEUSB201943-02-08, 2019.

Szczuciński, W.: The post-depositional changes of the onshore 2004 tsunami deposits on the Andaman Sea coast of Thailand, Nat. Hazards, 60, 115-133, https://doi.org/10.1007/s11069-0119956-8, 2012.

Video Nuugaatsiaq tsunami 1: Video Captures Moment When Tsunami Hits Greenland's West Coast, available at: https://wwwyoutubecom/watch? $\mathrm{v}=\mathrm{LzSUDBbSsPI}$, last access: 3 September 2020a.
Video Nuugaatsiaq tsunami 2: MEGA-TSUNAMI caused by LANDSLIDE devastates village| Greenland, Nuugaatsiaq, available at: https://www.youtube.com/watch?v=16bAhJSL2-o, last access: 3 September 2020 b.

Video Nuugaatsiaq tsunami 3: Nuugaatsiaq tsunami Rasmus, available at: , last access: 3 September 2020c.

Video Tsunami that reached Nuugaatsiaq and Illorsuit: A Landslide-Induced Tsunami Hit Nuugaatsiaq, Greenland, https:// www.youtube.com/watch?v=rSjjyiUpCAc, 3 September 2020d. 